\title{
Flow cytometric DNA analysis using cytokeratin labeling for identification of tumor cells in carcinomas of the breast and the female genital tract
}

\author{
Rainer Kimmig a,*, Pauline Wimberger ${ }^{\text {a }}$, \\ Thomas Kapsner ${ }^{b}$ and Peter Hillemanns ${ }^{a}$ \\ ${ }^{a}$ Department of Obstetrics and Gynecology, Klinikum \\ Grosshadern, Ludwig-Maximilians-University, \\ Munich, Germany \\ ${ }^{\mathrm{b}}$ Department of Medical Informatics, Biometry and \\ Epidemiology (IBE), Ludwig-Maximilians-University, \\ Marchioninistr. 15, D-81377 Munich, Germany
}

Received 24 July 2000

Accepted 20 March 2001

Flow cytometric assessment of DNA-ploidy and S-phase fraction in malignant tumors is compromised by the heterogeneity of cell subpopulations derived from the malignant and surrounding connective tissue, e.g., tumor, stromal and inflammatory cells. To evaluate the effect on quality of DNA cell cycle analysis and determination of DNA ploidy, cytokeratin labeling of epithelial cells was used for tumor cell enrichment in breast, ovarian, cervical and endometrial cancer prior to DNA analysis. In a prospective study, tumor cell subpopulations of 620 malignant tumors were labeled by a FITC-conjugated cytokeratin antibody (CK 5, 6, CK18 and CK 5, 6, 8 and CK 17, respectively) prior to flow cytometric cell cycle analysis. Compared to total cell analysis, detection rate of DNA-aneuploid tumors following cytokeratin labeling was increased from $62 \%$ to $76.5 \%$ in breast cancer, from $68 \%$ to $77 \%$ in ovarian cancer, from $60 \%$ to $80 \%$ in cervical cancer and from $30 \%$ to $53 \%$ in endometrial cancer. Predominantly in DNA-diploid tumors, a significantly improved detection of S-phase fraction of the tumor cells was shown due to the elimination of contaminating nonproliferating "normal cells". S-phase fraction following tumor cell enrichment

\footnotetext{
${ }^{*}$ Corresponding author: Rainer Kimmig, MD, Klinik und Poliklinik für Frauenheilkunde und Geburtshilfe der Universität München - Großhadern, D-81377 Munich, Germany. Tel.: + 49897095 2851/2858; Fax: + 49897095 5851; E-mail: Rainer.Kimmig@gyn.med.uni-muenchen.de.
}

was increased by $10 \%$ (mean) following cytokeratin staining in ovarian and endometrial cancer, by $30 \%$ in breast cancer and even by $70 \%$ in cervical cancer compared to total cell analysis. Thus, diagnostic accuracy of DNA-analysis was enhanced by cytokeratin labeling of tumor cells for all tumor entities investigated.

Keywords: Flow cytometry, DNA cell cycle analysis, cytokeratin

\section{Introduction}

Valid prognostic factors are necessary to predict the clinical course of malignant disease and the efficacy of intended treatment. Apart from clinicopathological parameters, DNA-ploidy and S-phase fraction as parameters for changes in genetic information and proliferation behaviour have been intensively studied in breast cancer and tumors of the female genital tract $[15,18]$. However, in spite of a great quantity of data no clear conclusion can be drawn from the available data. In breast cancer, for example, there is evidence for prognostic value of DNA-ploidy and S-phase fraction concerning survival in multivariate analysis in some studies $[35,53,64]$ whereas other studies could not confirm this observation $[4,10,50,63]$.

In ovarian cancer some studies show a prognostic value of DNA-ploidy [7,27,29,37] - especially for low grade ovarian cancer [52]. Other investigations found controversial results $[6,12,43]$. The same holds true for the $S$-phase fraction in ovarian cancer $[6,7,12]$.

Concerning cervical $[26,32,39,46]$ and endometrial cancer $[16,22]$ conflicting results were also reported with respect to clinical significance of determining DNA-ploidy and S-phase fraction. Recent findings on the basis of DNA ploidy-changes show a correlation between DNA content and the number of chromoso- 
mal aberrations and to centrosome disorders in cervix, i.e., aneuploidisation can serve as an early indicator of an aggressive behavior of premalignant cells [46].

Methodical problems in determination of DNAparameters may be responsible for the discrepant results. Suspensions of cells or nuclei isolated from malignant tumor tissue always contain - in addition to malignant cells - benign cells of the surrounding tissue, e.g., stromal and inflammatory cells and cellular debris. Therefore, DNA distribution of tumor cells is compromised by a varying amount of contaminating cells. Major problems concerning interpretation of DNA histograms and correct calculation of S-phase fraction may result: (1) Near DNAdiploid or near DNA-tetraploid tumors cannot be identified when a confluent overlapping with the DNAdiploid $\mathrm{G}_{0} \mathrm{G}_{1}$ - or $\mathrm{G}_{2} \mathrm{M}$-peak of contaminating cells is present. (2) Near diploid DNA-aneuploid tumors cannot be clearly classified as DNA-hypo- or hyperdiploid. (3) Small DNA-aneuploid tumor cell subpopulations may not be detectable, especially in the peritetraploid region. (4) Under-estimation of S-phase fraction due to admixture of all sorts of non-cycling nontumor cells may occur in DNA-diploid tumors. Cytokeratin labeling of epithelial cells [38] can be used to detect cytokeratin positive tumor cells [54]. It has been suggested that analysis after gating for cytokeratin shows different results compared to analysis of unlabeled cells in breast cancer [60]. A prospective study was initiated to evaluate the prognostic significance of cell cycle analysis based on cytokeratin labeling. The effect of cytokeratin labeling on results of DNA-ploidy determination and cell cycle distribution was analyzed in breast, ovarian, endometrial and cervical cancer.

\section{Materials and methods}

In total, fresh tumor tissue from 620 malignant tumors of the breast ( $n=327)$, the ovary $(n=129)$, the uterine cervix ( $n=91)$ and the endometrium $(n=73)$ was collected. The tumor samples of 620 patients could be evaluated. Overall fraction of not analysable samples was less than 3\%. DNA-ploidy could be analyzed in all samples, each of them containing more than 500, normally more than 1000 cells stained for cytokeratin. Criteria for analysis of S-phase fraction were described and defined in Results 3.2.

To get a single cell suspension suitable for flow cytometric analysis, the tissue was dissociated by a combined mechanical/enzymatic method as described
[30]. In brief, mechanical disaggregation of tissue was incubated in a prewarmed enzyme mixture in Dulbecco's phosphate buffered saline (PBS) consisting of $2 \mathrm{mg} / \mathrm{ml}$ trypsin (type III, $10000 \mathrm{U} / \mathrm{mg}$ protein, Sigma chemicals), $2 \mathrm{mg} / \mathrm{ml}$ collagenase (type I-S 180 U/mg solid, Sigma chemicals) and $0.2 \mathrm{mg} / \mathrm{ml}$ DNase (type I, $1548 \mathrm{U} / \mathrm{mg}$ protein, Sigma chemicals) at $37^{\circ} \mathrm{C}$ for $10 \mathrm{~min}$. Following several steps of washing and filtration, cell number and viability was determined by a cell counter and trypan blue exclusion. Cells were fixed in $70 \%$ methanol $\left(-20^{\circ} \mathrm{C}\right)$ for at least 24 hours. $5 \times 10^{4}$ to $2 \times 10^{5}$ cells per sample were resuspended in $0.5 \mathrm{ml} \mathrm{PBS} / 5 \%$ fetal calf serum (FCS) and labeled for cytokeratins using FITC-conjugated monoclonal mouse anti-human cytokeratin antibodies (DAKO-CK1/DAKO-CK (Dakopatts A/S); $100 \mu \mathrm{g}$ $\mathrm{IgG} / \mathrm{ml}$, dilution $1: 20$, at room temperature (RT), $30 \mathrm{~min}$, dark). Following centrifugation and washing in PBS/5\% FCS, cells were stained for DNA with $0.5 \mathrm{ml}$ PBS containing propidium iodide $(50 \mu \mathrm{g} / \mathrm{ml})$ and RNAse (Sigma type IAS, $1 \mathrm{mg} / \mathrm{ml}$ ) at $37^{\circ} \mathrm{C}$ for $10 \mathrm{~min}$. Negative controls were performed identically using a FITC-conjugated mouse $\mathrm{IgG}_{1}$-isoantibody. As controls for ploidy, cytokeratin staining and coefficient of variation $\left(\mathrm{CV} ; \mathrm{G}_{0} \mathrm{G}_{1}\right.$ peak) female human lymphocytes and HeLa cells were processed identically and measured prior to each measurement. Ten thousand to 40000 cells per sample were measured in a FACScan flow cytometer (488 nm Argon laser; Beckton Dickinson) equipped with Hewlett Packard hardware and a pulse processor for doublet discrimination. Data acquisition and analysis was performed with the Cellfitsoftware of BD. Following doublet exclusion each histogram was analysed for $\mathrm{CV}$ and position of the $\mathrm{G}_{0} \mathrm{G}_{1}$ peak of cytokeratin negative "normal" cells and cytokeratin positive "tumor" cells, respectively.

DNA ploidy was determined according to Hiddemann et al. [25] and classified as DNA-euploid (normal stemline), DNA-aneuploid (1 abnormal stemline) and DNA-multiploid (more than 1 abnormal stemline). Tumor proliferation was estimated by calculating percentages of $\mathrm{G}_{0} \mathrm{G}_{1^{-}}, \mathrm{S}$-, and $\mathrm{G}_{2} \mathrm{M}$-phase of each individual analyzable stemline using the SOBR method (sum of broadened rectangles) [3]. Each series of DNAanalysis was preceded by an external control containing human lymphocytes and HeLa-cells. Quality control has been performed as described previously [30,31].

The DNA index was calculated by the relationship of DNA-content of the tumor cell to DNA-content of the "normal" DNA-diploid somatic cell of the same or- 
ganism, i.e., the correlation of cytokeratin positive cells after gating to cytokeratin negative cells. First, DNAaneuploid subpopulations were identified by visual inspection. Median peak channel of the distribution of cytokeratin positive cells was measured and divided by median peak chanel of cytokeratin negative cells. A difference of more than 5\% was defined as DNAaneuploid. In addition, CV of cytokeratin positive and cytokeratin negative cells was determined. For quality control the same procedure was performed prior to each experiment for female lymphocytes and HeLa cells for external control.

The experimental data were analyzed with the use of SAS (SAS Institute Inc., Cary, NC) on a UNIX workstation. The different proportions of DNA-aneuploid tumors found with gating for cytokeratin positive cells compared to those without gating were described using a two-by-two table. Since no definitive reference test for determination of ploidy was available the results obtained with gating could only be described in relation to the results without gating. The McNemar test was used to test the null hypothesis that the results by the two methods are indistinguishable. In order to compare proportions from cell counts obtained by cell cycle analysis with a statistical test they were transformed to the angular scale using an arcsin transformation [48]. The coherence between categorial features was described by contingency-tabels and proofed with the $\chi^{2}$-test.

\section{Results}

Flow cytometric DNA-analysis following labeling of cytokeratin could be evaluated on tumor samples of 620 different patients. Median tissue weight of the sample was $0.33 \mathrm{~g}$ for breast, $0.90 \mathrm{~g}$ for ovarian, and $0.47 \mathrm{~g}$ and $0.45 \mathrm{~g}$ for cervical and endometrial cancer, respectively. Cell yield was considerably different for each tumor entity with a median of $0.9 \times 10^{6}$ cells $\times \mathrm{g}^{-1}$ for breast, $5.6 \times 10^{6}$ cells $\times \mathrm{g}^{-1}$ for ovarian, $8.2 \times 10^{6}$ cells $\times \mathrm{g}^{-1}$ and $10.8 \times 10^{6}$ cells $\times \mathrm{g}^{-1}$ for cervical and endometrial cancer. Median cell viability ranged from $80 \%$ to $85 \%$ for all tumor entities. Each cell suspension contained at least one cytokeratin negative and one cytokeratin positive cell subpopulation. In addition, even in DNA-aneuploid subpopulations of poorly differentiated tumors percentage of cytokeratin positive cells was more than $90 \%$ (in 182 of 197 tumors). No DNA-aneuploid subpopulation containing less than $60 \%$ cytokeratin positive cells was found.
The principle of DNA-analysis following cytokeratin staining and gating for cytokeratin positive cells is demonstrated in Fig. 1 for HeLa cells and normal human lymphocytes. Cytokeratin positive HeLa cells (Fig. 1b) can clearly be separated from cytokeratin negative lymphocytes which are similar to negative controls (Fig. 1a). Separate gating of total cells (Fig. 1c) on cytokeratin positive (Fig. 1e) and negative cells (Fig. 1d) provides DNA histograms free of overlap.

The coefficient of variation $(\mathrm{CV})$ of the $\mathrm{G}_{0} \mathrm{G}_{1}$-peak was determined in both cytokeratin positive and cytokeratin negative cells. CV of DNA-diploid cytokeratin negative cells as marker for the quality of cell preparation and measurement was quite similar for breast $(3.21 \pm 0.94 \%(\mathrm{SD}))$, ovarian $(3.19 \pm 0.95 \%)$, cervical $(3.07 \pm 0.82 \%)$ and endometrial $(3.3 \pm 0.97 \%)$ cancer. Surprisingly, $\mathrm{CV}$ of the $\mathrm{G}_{0} \mathrm{G}_{1}$ peak after cytokeratin labeling was considerably higher for all tumor entities, ranging from $3.76 \pm 0.97 \%$ (breast), $4.05 \pm 0.96 \%$ (ovary), $4.06 \pm 0.91 \%$ (endometrium) to $4.32 \pm 1.23 \%$ (cervix). Since this difference in CV between cytokeratin negative and cytokeratin positive cells cannot be explained by technical variables, most probably it may be attributed to properties of the tumor cells. Apart from variability in size and unspecific binding of propidium iodide, slight variations in DNA-content may be the reason for this observation.

In breast cancer, higher $\mathrm{CV}$ was correlated significantly to estrogen $(p=0.05)$ and progestin receptor negativity ( $p=0.003$ ). In ovarian cancer, the cell cycle phase fraction and the $\mathrm{CV}$ of the $\mathrm{G}_{0} \mathrm{G}_{1}$-peak did not correlate with clinico-histopathological parameters. In cervical cancer, adenocarcinomas showed a lower $\mathrm{CV}$ in comparison to squamous cell carcinomas $(p=0.05)$. In addition, higher FIGO-stage was correlated to higher $\mathrm{CV}$-values $(p=0.05)$. In endometrial cancer, we found no correlation between CV, FIGOstage, lymphnode status, grading, steroid receptors and lymphangiosis carcinomatosa.

\subsection{DNA-ploidy}

Detection of DNA-aneuploid subpopulations in total cells was compared to tumor cell enriched samples following cytokeratin gating prior to DNA-analysis. Ploidy was defined after gating. In breast cancer we found $16 \%$ DNA near-diploid cytokeratin positive cells. Since $319 / 327$ breast cancers were of ductale origin no correlation can made concerning different 

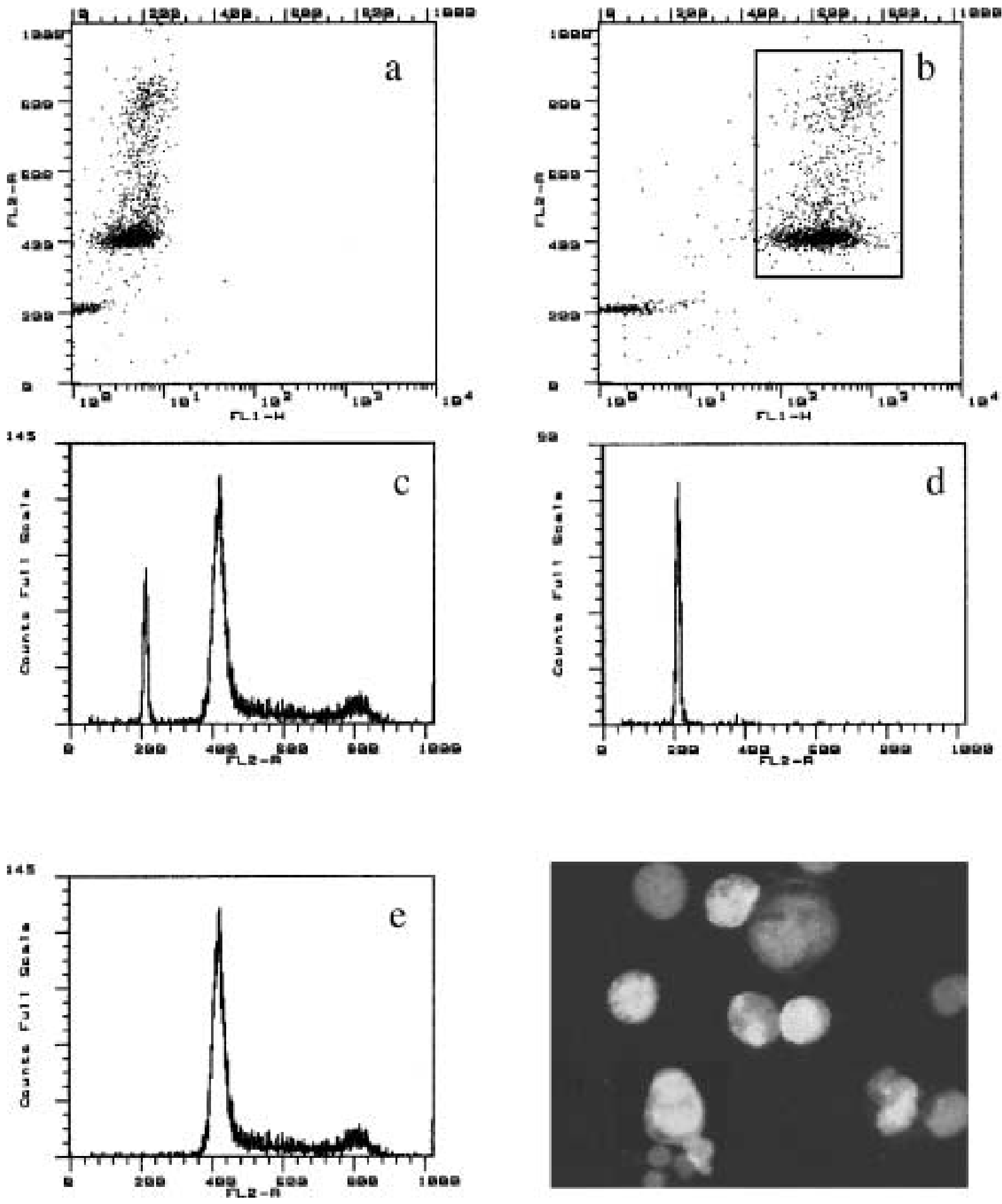

Fig. 1. HeLa cells and lymphocytes: Cytokeratin/DNA labeling. The dot-plots of the cytokeratin labeling (FL1-H, FITC, green, log, relative fluorescence values (RFV)) and DNA labeling (FL2-A, PI, red, linear, RFV) are demonstrated as negative control (a) and cytokeratin labeling (b). The histograms for the red fluorescence of DNA labeling are shown for all cells (c), FL2-A, PI, lin, RFV), for cytokeratin negative cells (d), FL2-A, PI, lin RFV) and for cytokeratin positive cells (e), FL2-A, PI, lin, RFV). Due to cytokeratin labeling cytokeratin separate analysis of cytokeratin positive cells (HeLa) can be differentiated from smaller lymphocytes (f). 
origin. $67 \%$ of invasive lobular breast cancers were diploid, but only 8 lobular carcinomes were detected.

For breast cancer, we found 125 (38.2\%) DNAdiploid tumors in the ungated samples. After cytokeratin gating only 77 (23.5\%) were confirmed (Table 1$)$.

In breast cancer, there was a distinct accumulation of the DNA-index at the peridiploid range and at the DNA-indices of 1.6 to 1.8. Tumors with a DNAindex $>2$ are less frequent (47/334 DNA-aneuploid subpopulations $=14 \%$ ). DNA-hypodiploid subpopulations were rare $(25 / 334=7 \%)$ (Fig. $2 a)$.

The data for ploidy analysis in ovarian cancer are summarized in Table 2. Whereas 41 (31.8\%) of the tumors were classified as DNA-diploid without tumor cell enrichment, this figure was reduced to 29 (22.5\%) when analysing cytokeratin positive cells.

In ovarian cancer, there was a clear accumulation in the peridiploid range and at a DNA-index of 1.5-1.7. In ovarian cancer we detected $24 \%$ near DNA-diploid cytokeratin positive cells.
Only 9\% (14/158 DNA aneuploid subpopulations) had a DNA-index $>2$. $10 \%(15 / 158)$ showed DNAhypodiploid subpopulations (Fig. 2b).

In Table 3, data for cervical cancer are summarized. $36(39.6 \%)$ of cervical carcinomas were determined as DNA-diploid in total cell analysis, but only $18(19.8 \%)$ were confirmed by analysis of cytokeratin positive cells.

In cervical cancer, we found a distinct accumulation in the slight DNA-hyperdiploid range and also in the range of 1.5-1.7. In cervix cancer we detected $31 \%$ DNA near-diploid cytokeratin positive cells. Tumors with a DNA-index $>2$ are also less frequent (9/103 DNA-aneuploid subpopulations $=9 \%)$. DNAhypodiploid subpopulations are present in 4\% (5/103) (Fig. 2c).

Data for endometrial cancer are shown in Table 4. The proportion of DNA-diploid tumors was considerably higher compared to the other malignancies. 17/73 endometrial cancers $(23.3 \%)$ were wrongly classified

Table 1

Breast cancer. Detection of DNA-aneuploid subpopulations dependent on gating of cytokeratin positive cells

\begin{tabular}{lcccccc}
\hline $\begin{array}{l}\text { DNA-aneuploid } \\
\text { subpopulations }(n)\end{array}$ & $\mathrm{CK}+0$ & $\mathrm{CK}+1$ & $\mathrm{CK}+2$ & $\mathrm{CK}+3$ & $\mathrm{CK}+4$ & $\begin{array}{c}\text { Total, } \\
\text { no cytokeratin }\end{array}$ \\
\hline no CK 0 & 77 & 44 & 4 & 0 & 0 & $125(38.2 \%)$ \\
no CK 1 & 0 & 132 & 22 & 2 & 0 & $156(47.7 \%)$ \\
no CK 2 & 0 & 0 & 39 & 3 & 0 & $42(12.8 \%)$ \\
no CK 3 & 0 & 0 & 0 & 3 & 0 & $3(0.9 \%)$ \\
no CK 4 & 0 & 0 & 0 & 0 & 1 & $1(0.3 \%)$ \\
\hline total, cytokeratin & 77 & 176 & 65 & 8 & 1 & $327(100 \%)$ \\
positive cells & $(23.5 \%)$ & $(53.8 \%)$ & $(19.9 \%)$ & $(2.4 \%)$ & $(0.3 \%)$ & \\
\hline
\end{tabular}

Number of DNA-aneuploid subpopulations was determined in single cell suspensions of 327 carcinomas of the breast. The tumors were classified in subgroups containing $0,1,2,3$ or 4 DNAaneuploid subpopulations for comparison of results with $(\mathrm{CK}+$ ) or without (no $\mathrm{CK}$ ) cytokeratin gating. Total numbers in each group are given on the right and at the bottom (\%).

Table 2

Ovarian cancer. Detection of DNA-aneuploid subpopulations dependent on gating of cytokeratin positive cells

\begin{tabular}{lcccccc}
\hline $\begin{array}{l}\text { DNA-aneuploid } \\
\text { subpopulations }(n)\end{array}$ & $\mathrm{CK}+0$ & $\mathrm{CK}+1$ & $\mathrm{CK}+2$ & $\mathrm{CK}+3$ & $\mathrm{CK}+4$ & $\begin{array}{c}\text { Total, } \\
\text { no cytokeratin }\end{array}$ \\
\hline no CK 0 & 29 & 11 & 1 & 0 & 0 & $41(31.8 \%)$ \\
no CK 1 & 0 & 62 & 15 & 0 & 0 & $77(59.6 \%)$ \\
no CK 2 & 0 & 0 & 9 & 1 & 0 & $10(7.8 \%)$ \\
no CK 3 & 0 & 0 & 0 & 0 & 1 & $1(0.8 \%)$ \\
\hline total, cytokeratin & 29 & 73 & 25 & 1 & 1 & $129(100 \%)$ \\
positive cells & $(22.5 \%)$ & $(56.6 \%)$ & $(19.4 \%)$ & $(0.8 \%)$ & $(0.8 \%)$ & \\
\hline
\end{tabular}

Number of DNA-aneuploid subpopulations was determined in single cell suspensions of 129 cancers of the ovary. The tumors were classified in subgroups containing $0,1,2,3$ or 4 DNAaneuploid subpopulations for comparison of results with $(\mathrm{CK}+)$ or without (no $\mathrm{CK}$ ) cytokeratin gating. Total numbers in each group are given on the right and at the bottom $(\%)$. 
Table 3
Cervical cancer detection of DNA-aneuploid subpopulations dependent on gating of cytokeratin positive cells

\begin{tabular}{lcccccc}
\hline $\begin{array}{l}\text { DNA-aneuploid } \\
\text { subpopulations }(n)\end{array}$ & $\mathrm{CK}+0$ & $\mathrm{CK}+1$ & $\mathrm{CK}+2$ & $\mathrm{CK}+3$ & $\mathrm{CK}+4$ & $\begin{array}{c}\text { Total, } \\
\text { no cytokeratin }\end{array}$ \\
\hline no CK 0 & 18 & 17 & 1 & 0 & 0 & $36(39.6 \%)$ \\
no CK 1 & 0 & 32 & 12 & 1 & 0 & $45(49.5 \%)$ \\
no CK 2 & 0 & 0 & 5 & 2 & 1 & $8(8.8 \%)$ \\
no CK 3 & 0 & 0 & 0 & 2 & 0 & $2(2.2 \%)$ \\
\hline total, cytokeratin & 18 & 49 & 18 & 5 & 1 & $91(100 \%)$ \\
positive cells & $(19.8 \%)$ & $(53.9 \%)$ & $(19.8 \%)$ & $(5.5 \%)$ & $(1.1 \%)$ & \\
\hline
\end{tabular}

Number of DNA-aneuploid subpopulations was determined in single cell suspensions of 91 carcinomas of the uterine cervix. The tumors were classified in subgroups containing $0,1,2,3$ or 4 DNA-aneuploid subpopulations for comparison of results with $(\mathrm{CK}+$ ) or without (no $\mathrm{CK}$ ) cytokeratin gating. Total numbers in each group are given on the right and at the bottom (\%).

Table 4

Endometrial cancer. Detection of DNA-aneuploid subpopulations dependent on gating of cytokeratin positive cells

\begin{tabular}{lccccc}
\hline $\begin{array}{l}\text { DNA-aneuploid } \\
\text { subpopulations }(n)\end{array}$ & $\mathrm{CK}+0$ & $\mathrm{CK}+1$ & $\mathrm{CK}+2$ & $\mathrm{CK}+3$ & $\begin{array}{c}\text { Total, } \\
\text { no cytokeratin }\end{array}$ \\
\hline no CK 0 & 34 & 17 & 0 & 0 & $51(69.9 \%)$ \\
no CK 1 & 0 & 18 & 1 & 0 & $19(26.0 \%)$ \\
no CK 2 & 0 & 0 & 2 & 1 & $3(4.1 \%)$ \\
\hline total, cytokeratin & 34 & 35 & 3 & 1 & $73(100 \%)$ \\
positive cells & $(46.6 \%)$ & $(48.0 \%)$ & $(4.1 \%)$ & $(1.3 \%)$ & \\
\hline
\end{tabular}

Number of DNA-aneuploid subpopulations was determined in single cell suspensions of 91 carcinomas of the endometrium. The tumors were classified in subgroups containing $0,1,2$ or 3 DNA-aneuploid subpopulations for comparison of results with $(\mathrm{CK}+$ ) or without (no $\mathrm{CK})$ cytokeratin gating. Total numbers in each group are given on the right and at the bottom (\%).

being DNA-diploid corresponding to one third of the tumors originally classified as DNA-diploid without cytokeratin staining.

In endometrial cancer, the high amount of DNAdiploid and slight DNA-hyperdiploid tumors (66/78 subpopulations with a DNA-index $\leqslant 1.3$ ) is striking in comparison to breast, ovarian and cervical cancer (Fig. 2d). Near-diploid cytokeratin positive cells were present in $37 \%$ in endometrial cancer.

In breast cancer, patients DNA-aneuploidy was correlated to less differentiated tumors (G III, $p<0.0001$ ) and positive axillary lymphnodes $(p=0.01)$. The same holds true for the DNA-index. In ovarian cancer, we found a significantly higher amount of DNAaneuploid tumors in patients with a higher FIGO-stage and a greater postoperative tumor rest $(p<0.0001)$. Similar results were seen for isolated consideration of tumors with a DNA-index $>1.3$, which showed a significant correlation with positive lymphnode state $(p=0.003)$. Neither in cervical nor in endometrial cancer we found any correlation between DNA-ploidy and clinico-histopathological parameters.

\subsection{S-phase fraction}

In addition to DNA ploidy, we performed cell cycle analyses to determine percentage of S-phase fraction. However, some requirements had to be met prior to admission for analysis. First, cell subpopulations had to consist of more than 1000 cells. Second, no interference of cell cycle distribution and debris had to be present and third, no overlay of different subpopulations had to be detectable which would have required a mathematical separation of curves. The comparison of mean S-phase fraction for DNA diploid/aneuploid tumors with or without cytokeratin gating include the same cases, i.e., only those cases for which ploidy status was not changed after gating. The comparison of the corresponding mean values should be more accurate if the calculation is made from the same cases.

Due to these rigid inclusion criteria $S$-phase fraction without cytokeratin gating could be determined in only $45 \%$ of breast, $53 \%$ of ovarian, $47 \%$ of cervical and $70 \%$ of endometrial cancers. Following gat- 


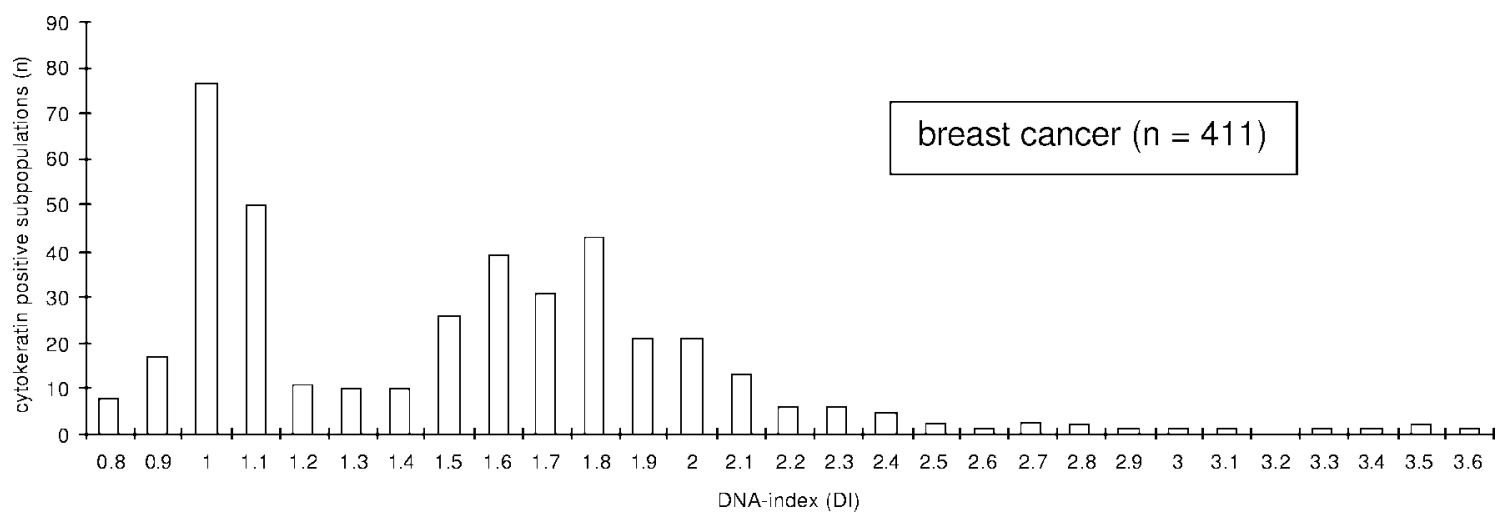

(a)

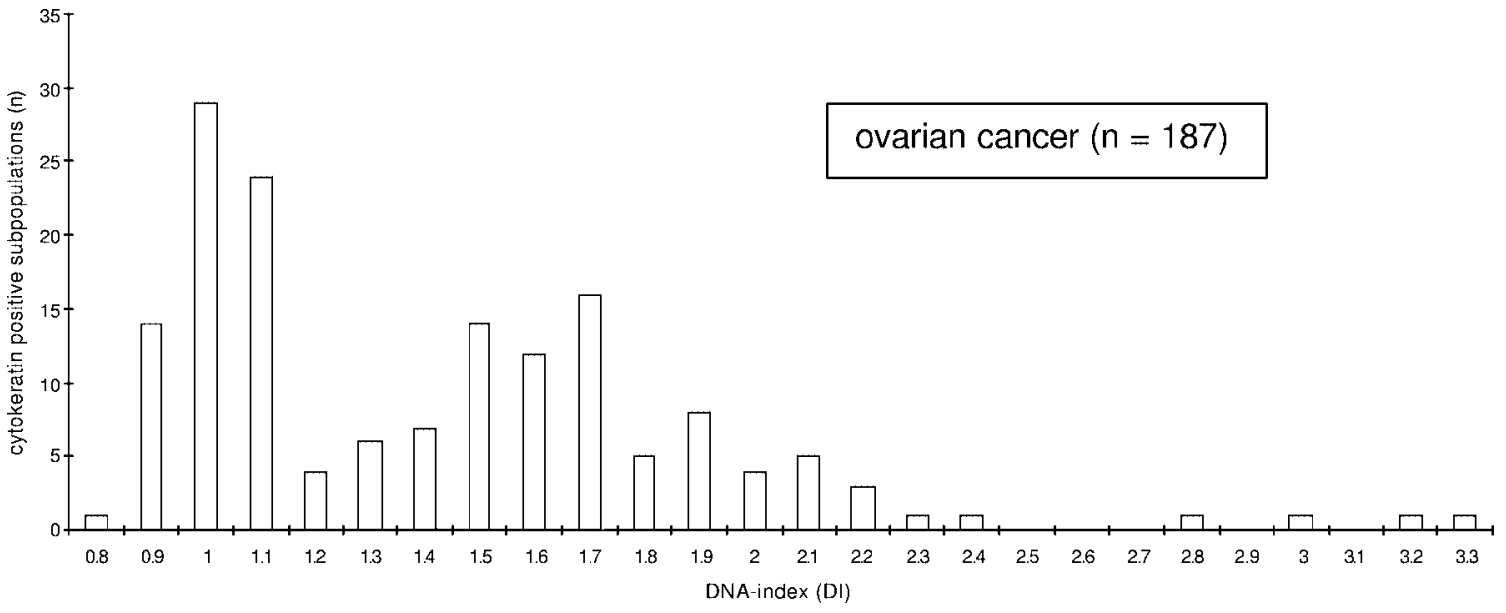

(b)

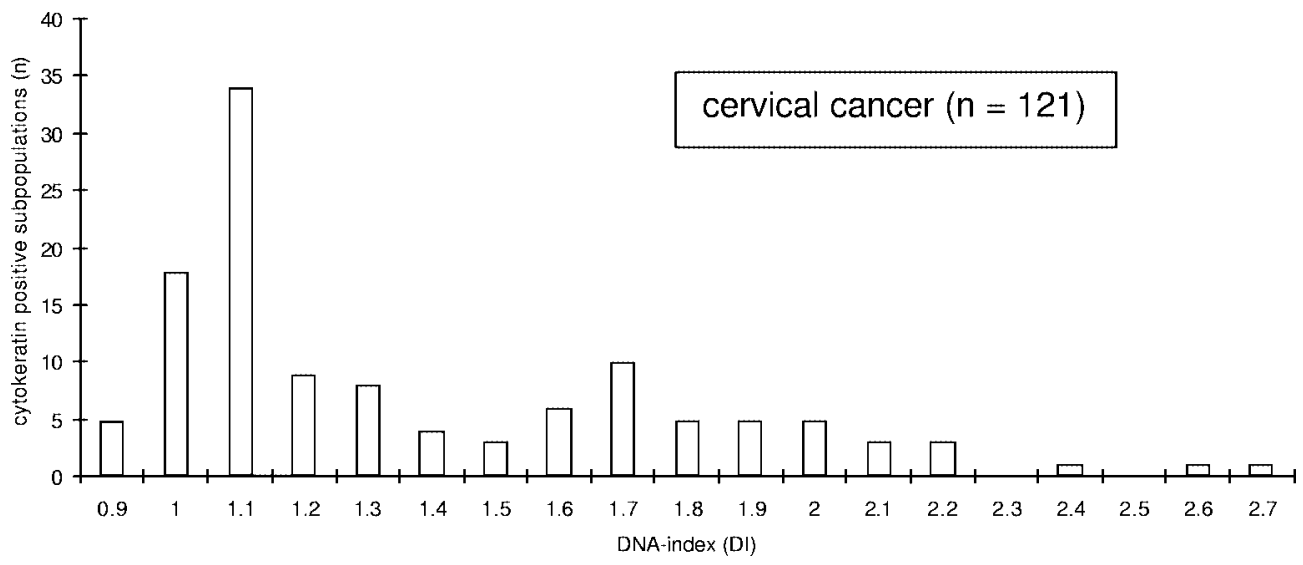

(c)

Fig. 2. Continued on next page. 


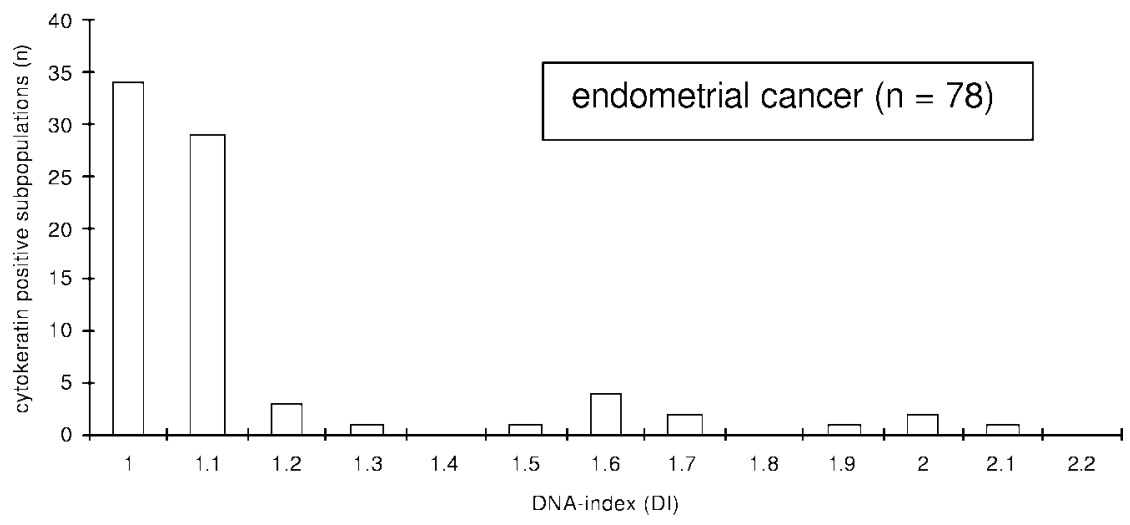

(d)

Fig. 2. DNA-index of cytokeratin positive subpopulations for carcinomas of the breast (a), ovary (b), cervix (c) and endometrium (d). The amount of DNA-aneuploid subpopulations following labeling with cytokeratin antibodies was determined in single cell suspensions. For 327 primary breast cancers the distribution of DNA-index of all DNA-aneuploid subpopulations $(n=334)$ was shown together with the DNA-diploid tumors $(n=77, \mathrm{DI}=1.0)$ (a). For 129 primary ovarian cancers distribution of DNA-index of all DNA-aneuploid subpopulations $(n=158)$ was demonstrated together with the DNA-diploid tumors $(n=29$, DI $=1.0)(b)$. In Fig. $2 c$ the distribution of DNA-index of all DNA-aneuploid subpopulations of 91 cervical cancers $(n=103)$ was shown together with the DNA-diploid tumors $(n=18, \mathrm{DI}=1.0)(\mathrm{c})$. The distribution of DNA-index of all DNA-aneuploid subpopulations of 73 primary endometrial carcinomas $(n=44)$ was shown together with the exclusive DNA-diploid tumors $(n=34, \mathrm{DI}=1.0)(\mathrm{d})$.

ing for cytokeratin positive cells, percentage of analyzable samples could be enhanced to $61 \%$ in breast, $85 \%$ in ovarian, $76 \%$ in cervical and $90 \%$ in endometrial cancer, respectively. The main limitation for determination of S-phase fraction in cytokeratin positive cells was the low number of cells in additionally detected DNA-aneuploid subpopulations and overlap of distribution curves in DNA-multiploid tumors.

S-phase fraction varied depending on tumor entity. The lowest S-phase fraction (mean \pm SD) was determined for breast cancer with $5.8 \pm 4.5 \%$ followed by endometrial cancer with $7.0 \pm 5.5 \%$ and ovarian cancer with $7.8 \pm 5 \%$. Highest $S$-phase values were found for cervical cancer with $12.3 \pm 5.4 \%$.

Determination of S-phase fraction can be compromised due to contamination of tumor cells by low proliferating "normal" cells. This may be true for DNAdiploid and near-diploid tumors since differentiation of cells without adequate markers is not possible. In order to estimate the error in determination of percentage of $\mathrm{S}$-phase fraction results of cell cycle analysis with and without cytokeratin gating were compared.

In breast cancer, the S-phase fraction following cytokeratin staining was $5.8 \pm 4.5 \%$ versus $4.4 \pm$ $3.6 \%$ without cytokeratin staining. In DNA-diploid tumors the S-phase fraction was $3.8 \pm 2.8 \%$ versus $2.9 \pm 2.5 \%$ without cytokeratin labeling and $6.3 \pm 4.6 \%$ versus $5.9 \pm 4.1 \%$ in DNA-aneuploid tumors. The S-phase fraction, therefore, in DNAaneuploid tumors was 1.7 times higher than in DNA- diploid tumors. S-phase fraction was correlated significantly to tumor size $(p=0.02)$, the lymphnode status $(p=0.02)$, the estrogen- $(p<0.006)$, progestin receptor $(p=0.0001)$ and to the histopathological grading $(p<0.0001)$.

In ovarian cancer, we found no difference in Sphase fraction with or without cytokeratin staining $(7.3 \pm 4.3 \%$ versus $7.3 \pm 4.7 \%)$. In DNA-diploid tumors, the S-phase fraction following cytokeratin staining tended to be higher with $5.8 \pm 4.0 \%$ versus $5.3 \pm 3.8 \%$, in contrary to DNA-aneuploid tumors with $8.4 \pm 4.8 \%$ versus $8.8 \pm 4.1 \%$. Similar to the results in breast cancer, the S-phase fraction was 1.5 times higher in DNA-aneuploid compared to DNAdiploid tumors. In addition, no correlation between cell cycle fraction and the clinicohistopathological parameters was seen.

In cervical cancer, we found a higher mean value for S-phase fraction with cytokeratin staining with $13.2 \pm 5.8 \%$ compared to $10.1 \pm 4.8 \%$ without cytokeratin gating. In DNA-diploid tumors, the S-phase fraction was $12.1 \pm 7.2 \%$ versus $7.1 \pm 3.6 \%$ without cytokeratin gating. In DNA-aneuploid tumors the S-phase fraction was $14.0 \pm 4.4 \%$ versus $12.3 \pm 4.3 \%$. Thus, S-phase fraction in DNA-aneuploid cervical cancers was only slightly higher (1.2 times) compared to DNAdiploid tumors. The S-phase fraction did not correlate with clinico-histopathological prognostic factors.

In endometrial cancer, mean values for the S-phase fraction with or without cytokeratin staining were 
$7.2 \pm 6.0 \%$ versus $6.7 \pm 5.3 \%$. In DNA-diploid tumors, the S-phase fraction was somewhat higher after cytokeratin staining with $6.5 \pm 3.8 \%$ versus $5.7 \pm 3.8 \%$ without staining. In DNA-aneuploid tumors, we found no difference with $8.4 \pm 7.0 \%$ versus $8.5 \pm 7.0 \%$. The Sphase fraction in DNA-aneuploid tumors was 1.3 times higher than in DNA-diploid ones. In addition, there was no significant correlation between S-phase fraction and clinico-histopathological prognostic factors.

\section{Discussion}

Valid assessment of prognosis is a prerequisite for risk adapted treatment in gynecologic oncology. Therefore, numerous parameters are evaluated for their prognostic significance in addition to classical clinicohistopathological prognostic factors. It is still a matter of debate, whether determination of DNA-ploidy or S-phase fraction may contribute to evaluation of prognosis since published data on prognostic relevance of DNA-ploidy and cell cycle analysis are controversial $[2,9,18,22,24]$.

Apart from differences in collectives, study design and statistical evaluation these differences may be explained by methodological problems during assessment of DNA-ploidy and cell cycle analysis. However, technique assessment of DNA-content to our opinion is crucial, in addition to our findings there is a great body of data in the literature indicating the lack of detection of DNA-aneuploid subpopulations and less appropriate determination of S-phase fraction without identifying of tumor cells also by the Vindelov method [11,21, $23,40,58]$.

There are several studies that indicate that gene mutations controlling chromosome segregation play a critical role in causing chromosome instability in cancer. Chromosomal aberrations consistent with impaired fidelity of chromosome segregation during mitosis have been shown to occur exclusively in aneuploid tumor cell lines and this is the key role of aberrant DNA content in carcinogenesis $[8,19,20,33,47$, $65]$. Genetic instability as measured by the number of chromosomal copy alterations per case, increases significantly at the transition from precursor lesions to invasive carcinomas and continues to increase with tumor stage. Aggressive tumors have a higher number of copy alterations per case [47]. Crude deviations from a normal, diploid DNA content could be observed at earlier stages than specific chromosomal copy number changes in cervical tumors [47]. In cervical carcino- genesis increased proliferative activity was already observed in low-grade dysplastic lesions. The initial increase occurs prior to the manifestation of chromosomal aberrations and persists in invasive disease [47]. Ghadimi et al. demonstrated the exclusive occurence of centrosome amplification and instability in all aneuploid tumor cell lines analyzed. The integrity of the centrosome plays a central role in the development of aneuploidy [20].

Prerequisite for flowcytometric detection of DNAaneuploid subpopulations in a cell mixture is a sufficient amount of tumor cells, as they would otherwise be superposed by other subpopulations. This applies especially to populations with a $\mathrm{G}_{0} \mathrm{G}_{1}$-peak in peridiploid and peritetraploid range, because most of the measured data of the contaminating cells of the surrounding normal tissue is localized here. The detection could be more difficult depending on the height of the variation coefficient of the $\mathrm{G}_{0} \mathrm{G}_{1}$-peak of normal cells, because even under optimal conditions, subpopulations with a deviation of DNA-content of less than $5 \%$ cannot be identified by a separate peak. In breast carcinoma, flow cytometry of unfixed tissue showed higher DNA measurement precision and a higher number of DNA nondiploid clones as compared to the fixed flow cytometry or to image cytometry [41]. Discordant cases were predominantly DNA neardiploid by flow cytometry of unfixed tissue but DNA-diploid by fixed tissue or by image cytometry [41]. Thus, each of the methods has its own advantages and limitations. Flow cytometry of unfixed tissue is superior to the other methods with respect to precise DNA index estimation [41]. Spyratos et al. examined DNA ploidy and Sphase fraction in breast cancer fine-needle cytopunctures by image and flow cytometry. The concordance rate between the two methods was $87 \%$. Flow cytometry was more rapid and adequate in a larger number of cases, image cytometry was more adequate in case of low cellularity, i.e., fewer than 5000 cells for analysis of the cell cycle [49]. Peiro et al. also showed an agreement in ploidy by flow and image cytometry in $87 \%$. However, flow cytometry detected aneuploidy more frequently than image cytometry [42].

The superposition of tumor cell populations by contaminating non-epithelial cells could be minimized with cytokeratin labeling of the epithelial cells. It has been shown for the DNA analysis of breast cancer tissue that the comparability between flow cytometry and image analysis is increased through immunolabelling with cytokeratin. The correlation between DNA indices measured by cytokeratin-gated flow cy- 
tometry and clinical prognostic parameters is also increased [57].

Primarily, intratumoral heterogeneity may contribute to heterogeneous results. In breast cancer, cervix and ovarian cancer, no relevant increase in DNA aneuploid subpopulations after cytokeratin gating with a DNA index close to 1 was detected. The distribution of DNA indices for the additional subpopulations detected after gating was similar compared to that of all tumors of the same origin for breast, ovarian and cervical cancer. This fact supports our hypothesis that differences in DNA-staining in fact reflect differences in DNA content. However, in endometrial carcinoma, we found more aneuploid subpopulations with a DNA index near 1 following cytokeratin gating (see Fig. 2). This may in fact be due to different stainability of epithelial and stromal cells in endometrial carcinoma. We can not preclude that this is a relative quantitative problem. We also observed this phenomenon occasionally in benign samples of endometrium in contrast to other tumor entities.

In breast cancer, differences in DNA-ploidy due to intratumoral heterogeneity were found in $19-32 \%$ [3, $14,44]$; with respect to DNA-index even in $13-64 \%$ [28]. Bergers et al. found heterogeneity in $53 \%$ of fresh and $38 \%$ of paraffin material analysing 6 biopsies of each tumor [5]; the differences were explained by more representative cell samples derived from cut surface in paraffin material. On the other hand, Fernö et al. suggest that low number of cells in DNAaneuploid subpopulations, position of the $G_{0} G_{1}$-peak in the peridiploid or peritetraploid region or overlay with debris may be responsible for the lack of detection of some DNA-aneuploid peaks [14]. Thus, intratumoral heterogeneity would not be due to strict topical separation of cell subpopulations but to topical differences in proportions of cell subsets. This suggestion is supported by the observation that in fact, no strict separation of DNA-diploid and DNA-aneuploid subpopulation could be found in image cytometry but a marked variation of proportion of DNA-diploid and DNAaneuploid subpopulations has been described $[1,36]$. If the assumption that tumor heterogeneity reflects quantitative topical differences in cell composition rather than strict topical separation, detection rate of DNAaneuploid subpopulations by image cytometry should be higher compared to flow cytometry despite of the far lower number of analyzed cells. In fact, there was a $10 \%$ higher detection rate for DNA-aneuploid subpopulations for image cytometry compared to flow cytometry $[13,51,59]$. On the other hand, in these stud- ies only $2-3 \%$ of DNA-aneuploid subpopulation were missed by image cytometry but detected by flow cytometry. Thus, it may be expected that enrichment of tumor cells and reduction of debris should result in a higher detection rate for DNA-aneuploid subpopulations and may compensate at least in part for intratumoral heterogeneity.

In our prospective study, we have shown that in breast cancer the detection rate for DNA-aneuploid tumors was $62 \%$. Similar results are shown by Frierson et al. who summarized flow cytometric analysis of 6,467 breast carcinomas [18]. Following cytokeratin gating, $77 \%$ of the tumors $(n=327)$ were found to be DNA-aneuploid, which approximates the figure found by Bergers et al. analysing 6 different biopsies of the same tumor [5]. For breast cancer, similar results are found by van der Linden et al. who described an increase of detection of DNA-aneuploid tumors from 59-72\% by cytokeratin staining [54].

To our knowledge, no previous prospective study of the detection rate of DNA-aneuploid tumors for ovarian, cervical and endometrial cancer has been published. Although the proportion of DNA-aneuploid tumors varies for the different tumor entities, we were able to demonstrate that cytokeratin gating allows enhanced detection of DNA-aneuploid subpopulation in all tumor entities. For ovarian cancer, proportion of DNA-aneuploid tumors following cytokeratin gating rose from $68 \%$ to $78 \%$, for cervical cancer from $60 \%$ to $80 \%$ and for endometrial cancer from $30 \%$ to $54 \%$.

Especially in ovarian cancer stage $\mathrm{I}$ it is very important to determine the rate of recurrence risk. A retrospective study showed for 1545 patients with invasive epithelial ovarian cancer stage I that the degree of differentiation is the most powerful prognostic indicator of disease-free survival. In addition, rupture during primary surgery of malignant ovarian tumors should be avoided [55]. For stage I ovarian cancer DNAploidy, extracapsular growth, tumor rupture and WHO histologic grade were significant independent prognostic factors for disease-free survival. DNA-ploidy determined by image cytometry adds objective independent prognostic information regarding both diseasefree and disease-specific survival in early ovarian cancer [52]. It is likely that environmental carcinogens interact with genomic instability. Yamasaki et al. suggest that carcinogens contribute to the induction of microsatellite instability and induce more mutations in those cells which show microsatellite instability. Sequences of different genes are mutated in different tumors [65]. However, inspite of adjuvant chemother- 
apy in stage I of ovarian cancer a $20 \%$ recurrency rate is found. Thereby DNA profiles are helpful, because conventional histologic grading is not sufficient. It has been shown in prospective studies that great genomic variations in nuclei indicate a recurrence risk of nearly $90 \%$ for the following 10 years. A high amount of genomic changes are a sign of genetic instability, i.e., a biologic potential for development of malignancy. In contrast, normal DNA profiles showed a small risk for recurrence [45]. This may indicate that patients with a normal DNA profile do not need a costintensive cytotoxic treatment with risk for relevant side effects.

Tumor cell proliferation may be another important predictor of tumor behaviour. With respect to S-phase fraction, marked differences of proliferating fraction were described in breast cancer when 6 different biopsies were analyzed ranging from $9.5-31.6 \%$ [5]. Taking 3 biopsies, $\mathrm{S}$-phase fraction ranged from $0-28 \%$ in ovarian cancer [27], whereas no significant difference for mean S-phase fraction was found in endometrial cancer [22]. When calculating mean S-phase fraction for breast carcinoma no difference could be shown between flow cytometry or image cytometry (7-9\%) $[34,59]$. However, apart from regional differences of cell proliferation, e.g., central vs. peripheral tumor areas, varying admixture of contaminating DNA-diploid cells of the tumor matrix will have impact on results of cell cycle analysis [36]. There are only few papers reporting on the influence of cytokeratin labeling for tumor cell enrichment on determination of S-phase fraction in breast cancer [56,60-62,66]. Mean S-phase fractions with and without gating for cytokeratin positive cells are given by Zarbo with $11.5 \%$ vs. $8.7 \%$ ( $n=23)$, by Visscher with $12 \%$ vs. $8.9 \%(n=33)$ and by Wingren with $4.6 \%$ vs. $4.1 \%(n=65)$. The differences of absolute values of S-phase fractions are most probably explained by differences in tumor preparation and analysis system. For example, following correction for background debris, S-phase fraction is reduced by nearly $50 \%$ (6.7\% vs. $12 \%$ ) [56]. Our data $(n=133)$ fit well to those of Wingren with $4.9 \%$ vs. $4.3 \%$ dependent on cytokeratin gating. As we have shown, calculation of S-phase fraction from DNA-diploid tumors was primarily influenced by admixture of DNA-diploid cells of the tumor matrix [30,31]. With respect to cell cycle analysis following cytokeratin labeling, no data is published for ovarian, cervical and endometrial cancer. Highest impact of cytokeratin gating on calculated S-phase fraction was found for cervical carcinoma, in which value of S-phase fraction was increased nearly two-fold. The effect on S-phase fraction of ovarian and endometrial cancer was only marginal. These findings can be explained by the high cellularity of ovarian and endometrial cancer with small stromal and inflammatory component in contrast to the high stromal component in breast cancer and the high incidence of inflammatory infiltration in cervical cancers. In all tumor entities number of samples with analyzable S-phase fraction was considerably enhanced.

Concerning the differences between S-phase fraction in DNA-diploid and DNA-aneuploid tumor subpopulations, Bernabei [6] described S-phase fraction of $7 \%$ in DNA-diploid compared to $14 \%$ in DNAaneuploid ovarian cancers. This difference was also detectable in our analysis, but to a smaller extent $(5.8 \%$ vs. $8.4 \%$ ).

Thus, the results of Friedlander et al. were confirmed, in that DNA-aneuploid tumors show a higher proliferation than DNA-diploid [17]. In addition, our data confirm the hypothesis of Friedlander that the Sphase fraction of DNA-diploid tumors was underestimated due to superposition of non-proliferating normal cells and was overestimated in DNA-aneuploid tumors due to interference with $\mathrm{G}_{2} \mathrm{M}$-phase of DNAdiploid populations. Although the differences of mean are small, there are marked differences in individual samples causing misclassification to the high or low proliferating group.

In summary, we have shown that tumor cell enrichment by gating of cytokeratin positive cells can optimize the detection of DNA-aneuploid subpopulations and determination of S-phase fraction in individual tumor samples. It was recommended as early as 1989 to perform prospective studies on the prognostic impact of DNA-analysis following enrichment of tumor cells instead of total cells from malignant tumors. It has been speculated that this will be the future of flow cytometry in DNA-analysis due to more reliable and valid data $[11,21,23,58]$. However, up to now the promising data concerning prognostic significance of S-phase fraction in breast cancer determined following cytokeratin gating [60-62] are not confirmed by other studies. No studies at all are published evaluating the impact of cytokeratin gating on prognostic significance of DNA-ploidy in breast cancer both DNA-ploidy and S-phase fraction in ovarian, cervical and endometrial cancer. On the basis of the presented data, however, it may be suggested that evaluation of prognostic significance of DNA-parameters can be validated by cytokeratin gating. Therefore, we intend to correlate clinical outcome of patients to DNA-parameters prospectively assessed in this study to evaluate clinical significance of the presented results. 


\section{Acknowledgements}

We wish to thank Dieta Egner and Marianne Fileki for excellent technical assistance. This study was supported by a grant from the "Münchner Medizinische Wochenschrift" (MMW).

\section{References}

[1] U.G. Askensten, A.K. von Rosen, R.S. Nilsson and G.U. Auer, Intratumoral variations in DNA distribution patterns in mammary adenocarcinomas, Cytometry 10 (1989), 326-333.

[2] H. Beerman, P.M. Kluin, J. Hermans, C.J.H. van de Velde and C.J. Cornelisse, Prognostic significance of DNA-ploidy in a series of 690 primary breast cancer patients, Int. J. Cancer 45 (1990), 34-39.

[3] H. Beerman, V.T. Smit, P.M. Kluin, B.A. Bonsing, J. Hermans and C.J. Cornelisse, Flow cytometric analysis of DNA stemline heterogeneity in primary and metastatic breast cancer [see comments], Cytometry 12 (1991), 147-154.

[4] J.A.M. Belion, J.P.A. Baak, P.J. van Diest, B.N.L.H.M. Misere, G.A. Meijer and L. Bergers, Prognostic value of image and flow cytometric DNA ploidy assessments in invasive breast cancer, Electron. J. Pathol. Histol. 3 (1997), 57-70.

[5] E. Bergers, P.J. van Diest and J.P. Baak, Tumour heterogeneity of DNA cell cycle variables in breast cancer measured by flow cytometry, J. Clin. Pathol. 49 (1996), 931-937.

[6] V.M. Bernabei, D.S. Miller, K.D. Bauer, T.M. Murad, A.W. Rademaker and J.R. Lurain, Flow cytometric evaluation of epithelial ovarian cancer, Am. J. Obstet. Gynecol. 162 (1990), 1584-1590.

[7] R.J. Brescia, R.A. Barakat, U. Beller, G. Frederickson, M.J. Suhrland, N. Dubin and R.I. Demopoulos, The prognostic significance of nuclear DNA content in malignant epithelial tumors of the ovary, Cancer 65 (1990), 141-147.

[8] D.P. Cahill, L.T. da Costa, E.B. Carson-Walter, K.W. Kinzler, B. Vogelstein and C. Lengauer, Characterization of MAD2B and other mitotic spindle checkpoint genes, Genomics $\mathbf{5 8}$ (1999), 181-187.

[9] G.M. Clark, L.G. Dressler, M.A. Owens, G. Pounds, T. Oldaker and W.L. McGuire, Prediction of relapse or survival in patients with node-negative breast cancer by DNA flow cytometry [see comments], N. Engl. J. Med. 320 (1989), 627-633.

[10] C.S. Dowle, A. Owainati, A. Robins, K. Burns, I.O. Ellis, C.W. Elston and R.W. Blamey, Prognostic significance of DNA content of human breast cancer, Br. J. Surg. 74 (1987), 133-136.

[11] L.G. Dressler and S.A. Bartow, DNA flow cytometry in solid tumors: practical aspects and clinical applications, Semin. Diagn. Pathol. 6 (1989), 55-82.

[12] E. Erba, P. Ubezio, S. Pepe, M. Vaghi, S. Marsoni, W. Torri, C. Mangioni, F. Landoni and M. d'Incalci, Flow cytometric analysis of DNA content in human ovarian cancer, Br. J. Cancer 60 (1989), 45-50.
[13] A.G. Fallenius, U.G. Askensten, L.K. Skoog and G.U. Auer, The reliability of microspectophotometric and flow cytometric nuclear DNA measurements in adenocarcinomas of the breast, Cytometry 8 (1987), 260-266.

[14] M. Fernö, B. Baldetrop, S.B. Ewers, I. Idvall, H. Olsson, H. Sigurdsson and D. Killander, One or multiple samplings for flow cytometric DNA analyses in breast cancer-prognostic implications?, Cytometry 13 (1992), 241-249.

[15] H. Fox, Clinical value of new techniques of gynecological tumor assessment, Int. J. Gynecol. Cancer 7 (1997), 337-349.

[16] L.G. Friberg, H. Noren and U. Delle, Prognostic value of DNA ploidy and S-phase fraction in endometrial cancer stage I and II: a prospective 5-year survival study, Gynecol. Oncol. 53 (1994), 64-69.

[17] M.L. Friedlander, I.W. Taylor, P. Russell, E.A. Musgrove, D.H. Hedley and M.H. Tattersall, Ploidy as a prognostic factor in ovarian cancer, Int. J. Gynecol. Pathol. 2 (1983), 55-63.

[18] H.F. Frierson, Jr., Ploidy analysis and S-phase fraction determination by flow cytometry of invasive adenocarcinomas of the breast, Am. J. Surg. Pathol. 15 (1991), 358-367.

[19] R.D. Gardner and D.J. Burke, The spindle checkpoint: two transitions, two pathways, Trends.Cell. Biol. 10 (2000), 154-158.

[20] B.M. Ghadimi, D.L. Sackett, M.J. Difilippantonio, E. Schrock, T. Neumann, A. Jauho, G. Auer and T. Ried, Centrosome amplification and instability occurs exclusively in aneuploid, but not in diploid colorectal cancer cell lines, and correlates with numerical chromosomal aberrations, Genes Chromosomes Cancer 27 (2000), 183-190.

[21] K. Goerttler, Purification kinetics of human tumors measured by flow cytometry, Acta Histochem. Suppl. 39 (1990), 49-60.

[22] T.E. Gudmundsson, T. Hogberg, P. Alm, H. Anderson, B. Baldetrop, M. Fernö, E. Langstrom and D. Killander, The prognostic information of DNA ploidy and S-phase fraction may vary with histologic grade in endometrial carcinoma, Acta Oncol. 34 (1995), 803-812.

[23] D.W. Hedley, G.M. Clark, C.J. Cornelisse, D. Killander, T. Kute and D. Merkel, Consensus review of the clinical utility of DNA cytometry in carcinoma of the breast. Report of the DNA Cytometry Consensus Conference, Cytometry 14 (1993), 482-485.

[24] D.W. Hedley, C.A. Rugg and R.D. Gelber, Association of DNA index and S-phase fraction with prognosis of nodes positive early breast cancer, Cancer Res. 47 (1987), 4729-4735.

[25] W. Hiddemann, J. Schumann, M. Andreeff, B. Barlogie, C.J. Herman, R.C. Leif, B.H. Mayall, R.F.G. Murphy and A.A. Sandberg, Convention on nomenclature for DNA cytometry, Cytometry 5 (1984), 445-446.

[26] A. Jakobsen, P. Bichel and M. Vaeth, New prognostic factors in squamous cell carcinoma of cervix uteri, Am. J. Clin. Oncol. 8 (1985), 39-43.

[27] J. Kaern, C.G. Trope, G.B. Kristensen, K.M. Tveit and E.O. Pettersen, Evaluation of deoxyribonucleic acid ploidy and S-phase fraction as prognostic parameters in advanced epithelial ovarian carcinoma: a prospective study, Am. J. Obstet. Gynecol. 170 (1994), 479-487.

[28] O.P. Kallioniemi, Comparison of fresh and paraffin-embedded tissue as starting material of DNA flow cytometry and evaluation of intratumor heterogeneity, Cytometry 9 (1988), 164-169. 
[29] S.K. Khoo, T. Hurst, J. Kearsley, D. Dickie, K. Free, P.G. Parsons, S. Whitaker and B. Ward, Prognostic significance of tumour ploidy in patients with advanced ovarian carcinoma, $G y$ necol. Oncol. 39 (1990), 284-288.

[30] R. Kimmig, H. Spelsberg, T. Kapsner, M. Untch and H. Hepp, Flow cytometric DNA analysis of breast cancer by two colour method using cytokeratin labeling for identification of tumour cells, Analyt. Cell. Pathol. 7 (1994), 205-215.

[31] R. Kimmig, T. Kapsner, H. Spelsberg, M. Untch and H. Hepp, DNA cell-cycle analysis of cervical cancer by flow cytometry using simultaneous cytokeratin labeling for identification of tumour cells, J. Cancer Res. Clin. Oncol. 121 (1995), 107-114.

[32] A. Leminen, J. Paavonen, E. Vesterinen, M. Forss, T. Wahlstrom, P. Kulomaa and M. Lehtinen, Deoxyribonucleic acid flow cytometric analysis of cervical adenocarcinoma: prognostic significance of deoxyribonucleic acid ploidy and S-phase fraction, Am. J. Obstet. Gynecol. 162 (1990), 848-853.

[33] C. Lengauer, K.W. Kinzler and B. Vogelstein, Genetic instabilities in human cancers, Nature 396 (1998), 643-649.

[34] P. Luzi, A. Bruni, P. Mangiavacchi, G. Cevenini, D. Marini, and P. Tosi, Ploidy pattern and cell cycle in breast cancer as detected by image analysis and flow cytometry, Cytometry 18 (1994), 79-87.

[35] H.A. Mat-Sakim, R.N.G. Naguib, M.S. Lakshmi, V. Wadehra, T.W.J. Lennard, J. Bhatavdekar and G.V. Sherbet, Analysis of image cytometry data of fine needle aspirated cells of breast cancer patients: A comparison between logistic regression and artificial neural networks, Anticancer Res. 18 (1998), 2723-2726.

[36] W.E. Mesker, M.J. Eysackers, M.C. Ouwerkerk van Velzen, A.M. van Friel Kulker and J.S. Ploem, Discrepancies in ploidy determination due to specimen sampling errors, Anal. Cell. Pathol. 1 (1989), 87-95.

[37] C. Millot and J. Dufer, Clinical applications of image cytometry to human tumour analysis, Histol. Histopathol. 15 (2000), $1185-1200$

[38] R. Moll, W.W. Franke, D.L. Schiller, G. Geiger and R. Krepler, The catalog of human cytokeratins: patterns of expression in normal epithelia, tumours and cultured cells, Cell 31 (1982), $11-24$.

[39] H.N. Nguyen, B.U. Sevin, H.E. Averette, P. Ganjei, J. Perras, R. Ramos, R. Angioli, D. Donato and M. Penalver, The role of DNA index as a prognostic factor in early cervical carcinoma, Gynecol. Oncol. 50 (1993), 54-59.

[40] S.M. O`Reilly, D.M. Barnes, R.S. Camplejohn, J. Bartkova, W.M. Gregory and M.A. Richards, The relationship between c-erbB-2 expression, S-phase fraction and prognosis in breast cancer, Br. J. Cancer 63 (1991), 444-446.

[41] G.L. Ottesen, I.J. Christensen, J.K. Larsen, J. Larsen, J. Christiansen, B. Baldetrop, T. Linden, B. Hansen and J.A. Andersen, DNA ploidy analysis in breast carcinoma. Comparison of unfixed and fixed tissue analyzed by image and flow cytometry, Anal. Quant. Cytol. Histol. 19 (1997), 413-422.

[42] G. Peiro, E. Lerma, M.A. Climent, M.A. Segui, M.C. Alonso and J. Prat, Prognostic value of S-phase fraction in lymphnode-negative breast cancer by image and flow cytometric analysis, Mod. Pathol. 10 (1997), 216-222.
[43] J. Pfisterer, F. Kommoss, W. Sauerbrei, H. Renz, A. du Bois, M. Kiechle Schwarz and A. Pfleiderer, Cellular DNA content and survival in advanced ovarian carcinoma, Cancer 74 (1994), 2509-2515.

[44] M.U. Prey, J.S. Meyer, K.R. Stone and R.W. McDivitt, Heterogeneity of breast carcinomas determined by flow cytometric analysis, J. Surg. Oncol. 29 (1985), 35-39.

[45] A. Reith, Telemedizin am norwegischen Krebszentrum Radiumhospitalet - Erfahrungen und Zukunft, Telemed, Berlin, 2000.

[46] A. Reith, B. Risberg and J. Sudbo, New relevance for prognostic value of DNA ploidy in premalignant epithelial lesions, Cytopathology 11 (2000), 406.

[47] T. Ried, K. Heselmeyer-Haddad, H. Blogen, E. Schröck and G. Auer, Genomic changes defining the genesis, progression, and malignancy potential in solid human tumors: a phenotype/genotype correlation, Genes Chromosomes Cancer $\mathbf{2 5}$ (1999), 195-204.

[48] G.W. Snedecor and W.G. Cochran, Statistical Methods, 6th edn, The Iowa State University Press, Ames, Iowa, USA, 1973, pp. 327-329.

[49] F. Spyratos and M. Brifford, DNAA ploidy and S-phase fraction by image and flow cytometry in breast cancer fine-needle cytopunctures, Mod. Pathol. 10 (1997), 556-563.

[50] O. Stal, S. Wingren, J. Carstensen, L.E. Rutqvist, L. Skoog, C. Klintenberg and B. Nordenskjold, Prognostic value of DNA ploidy and S-phase fraction in relation to estrogen receptor content and clinicopathological variables in primary breast cancer, Eur. J. Cancer Clin. Oncol. 25 (1989), 301-309.

[51] B. Susnik, N. Poulin, D. Philipps, J. Leriche and B. Palcic, Comparison of DNA measurement performed by flow and image cytometry of embedded breast tissue sections, Anal. Quant. Cytol. Histol. 17 (1995), 163-171.

[52] C. Trope, J. Kaern, T. Hogberg, V. Abeler, B. Hagen, G. Kristensen, M. Onsrud, E. Pettersen, P. Rosenberg, R. Sandvei, K. Sundfor and I. Vergote, Randomized study on adjuvant chemotherapy in stage I high-risk ovarian cancer with evaluation of DNA-ploidy as prognostic instrument, Ann. Oncol. 11 (2000), 281-288.

[53] J.C. Van der Linden, J. Lindeman, J.P. Baak, C.J. Meijer and C.J. Herman, The Multivariate Prognostic Index and nuclear DNA content are independent prognostic factors in primary breast cancer patients, Cytometry 10 (1989), 56-61.

[54] J.C. Van der Linden, C.J. Herman, J.G. Boenders, M.M. van de Sandt and J. Lindeman, Flow cytometric DNA content of fresh tumor specimens using kertin.-antibody as second stain for two-parameter analysis, Cytometry 13 (1992), 163-168.

[55] I. Vergote, J. De Brabanter, A. Fyles, K. Bertelsen, N. Einhorn, P. Sevelda, M.E. Gore, J. Kaern, H. Verrelst, K. Sjövall, D. Timmerman, J. Vandewalle, M. van Gramberen and C.G. Trope, Prognostic importance of degree of differentiation and cyst rupture in stage I invasive epithelial ovarian carcinoma, Lancet $\mathbf{3 5 7}$ (2001), 176-182.

[56] D.W. Visscher, R.J. Zarbo, G. Jacobsen, A. Kambouris, G. Talpos, W. Sakr and J.D. Crissman, Multiparametric deoxyribonucleic acid and cell cycle analysis of breast carcinomas by flow cytometry. Clinicopathologic correlations, Lab. Invest. 62 (1990), 370-378. 
[57] S.L. Willeboordse, W. Velehorshi, B. Peka, C.A. Ambrosius, R. Bollmann, I. Brightman and W.P. Kunze, Immunoselection for cytokeratin in the flow cytometric DNAA analysis of breast cancer tissue - DNA ploidy and S-phase fraction by image and flow cytometry, Electron. J. Pathol. Histol. 4 (1998), 40-60.

[58] G.D. Wilson, The future of flow cytometry, BJR 24 (Suppl.) (1992), 158-162.

[59] S. Wingren, T. Hatschek, O. Stal, B. Boeryd and B. Nordensjold, Comparison of static and flow cytofluorometry for stimation of DNA index and S-phase fraction in fresh and paraffinembedded breast carcinoma tissue, Acta Oncol. 27 (1988), 793-797.

[60] S. Wingren, O. Stal, J. Carstensen, X.F. Sun and B. Nordensjold, S-phase determination of immunoselected cytokeratincontaining breast cancer cells improves the prediction of recurrence, Br. Cancer Res. Treat. 29 (1994), 179-187.

[61] S. Wingren, O. Stal and B. Nordensjold, Flow cytometric analysis of S-phase fraction in breast carcinomas using gating on cells containing cytokeratin. South East Sweden Breast Cancer Group, Br. J. Cancer 69 (1994), 546-549.

[62] S. Wingren, O. Stal, S. Sullivan, A. Brisfors and B. Nordenskjold, S-phase fraction after gating on epithelial cells predicts recurrence in node-negative breast cancer, Int. J. Cancer $\mathbf{5 9}$ (1994), 7-10.

[63] T.E. Witzig, J.N. Ingle, S.S. Cha, D.J. Schaid, R.L. Tabery, L.E. Wold, C. Grant, N.J. Gonchoroff and J.A. Katzmann, DNA ploidy and the percentage of cells in S-phase as prognostic factors for women with lymph node negative breast cancer, Cancer 74 (1994), 1752-1761.

[64] M.T. Wyss-Desserich, R. Caduff-Joos, P. Wyss, C. Rageth, E. Wight, C. Unger, H. Walt and U. Haller, Premenopausal node-negative breast cancer: may adjuvant chemotheray be indicated by the analysis of nuclear DNA dynamics?, Br. Cancer Res. Treat. 42 (1997), 253-263.

[65] H. Yamasaki and N. Mironov, Genomic instability in multistage carcinogenesis, Toxicol. Lett. 112-113 (2000), 251-256.

[66] R.J. Zarbo, D.W. Visscher and J.D. Crissman, Two-color multiparametric method for flow cytometric DNA analysis of carcinomas using staining for cytokeratin and leukocyte-common antigen, Anal. Quant. Cytol. Histol. 11 (1989), 391-402. 


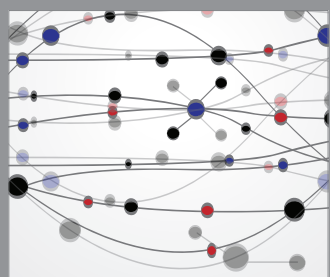

The Scientific World Journal
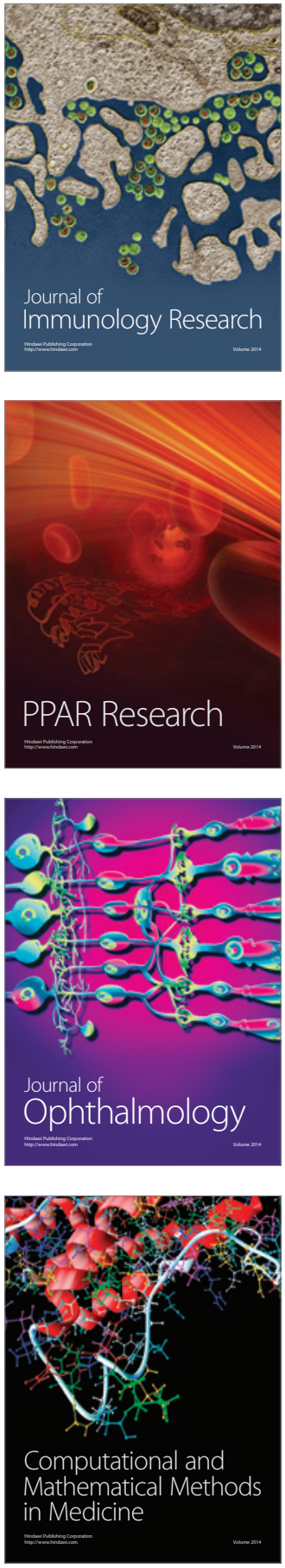

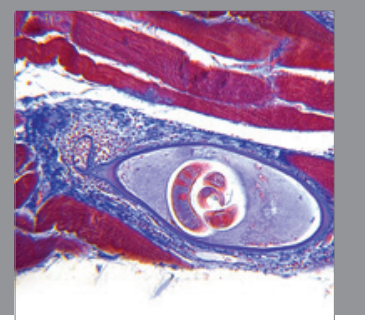

Gastroenterology

Research and Practice
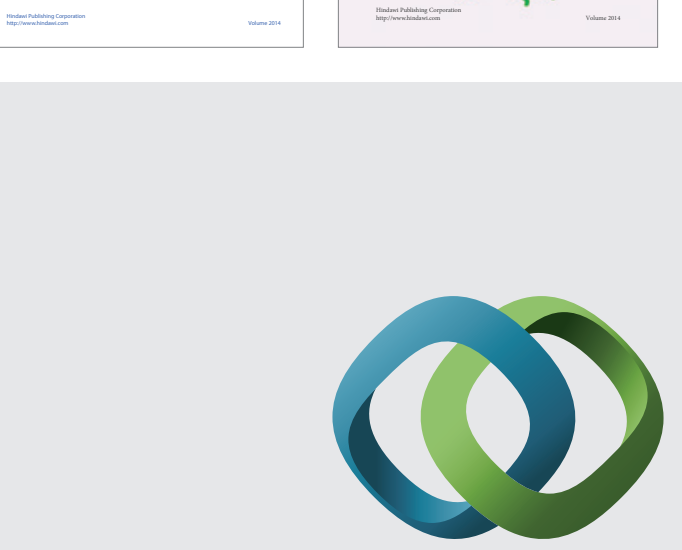

\section{Hindawi}

Submit your manuscripts at

http://www.hindawi.com
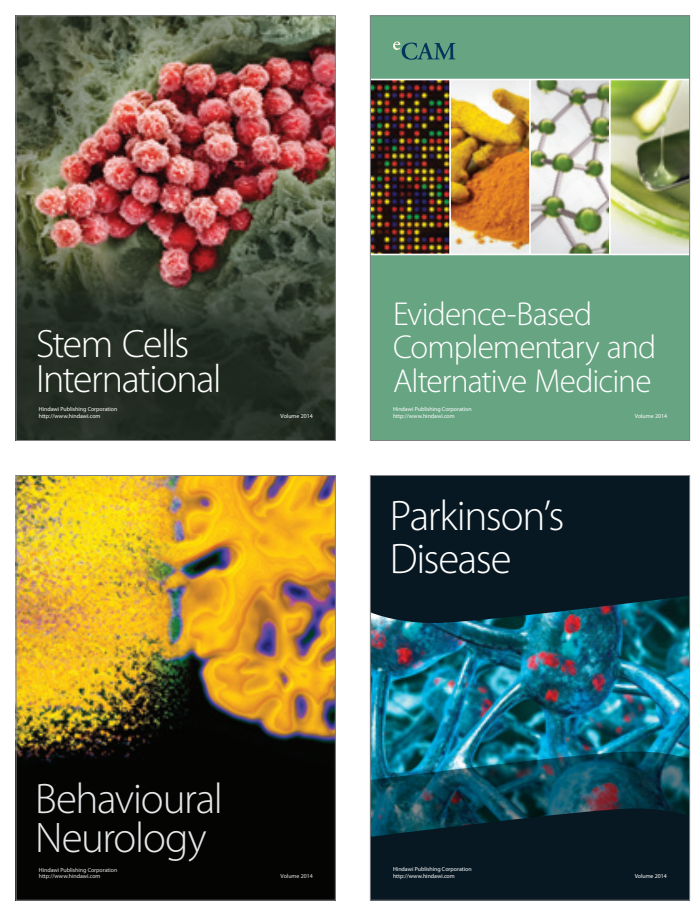

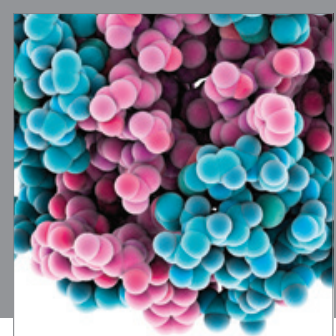

Journal of
Diabetes Research

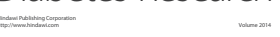

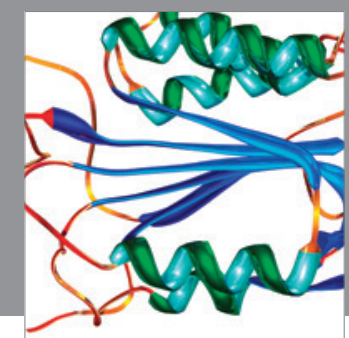

Disease Markers
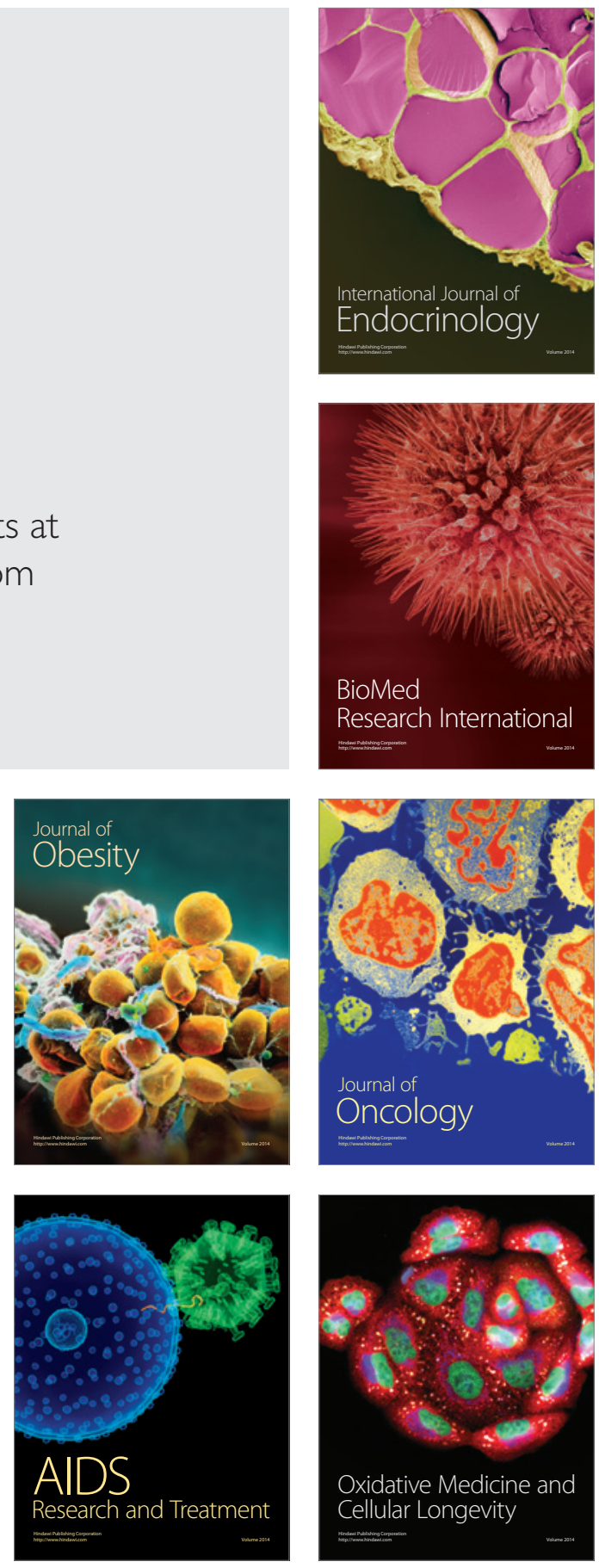